\title{
Reading, Questioning, and Answering (RQA) Strategies': an Alternative to Empowering Undergraduate Student Thinking Abilities
}

\author{
Harun Nasrudin \\ Chemistry Department \\ Universitas Negeri Surabaya \\ Surabaya, Indonesia \\ harunnasrudin@unesa.ac.id
}

\author{
Utiya Azizah* \\ Chemistry Department \\ Universitas Negeri Surabaya \\ Surabaya, Indonesia
}

\begin{abstract}
Reading, Questioning, and Answering (RQA) is a constructivist based learning strategy. The implementation of RQA can motivate undergraduate students to read the assigned material and have an impact on improving the understanding of learning material. This study aims to describe undergraduate students' thinking abilities in the Authentic Assessment of Knowledge, Skills, and Attitude material in the Process and Learning Outcomes Assessment of Chemistry (PLOAC) subject through the implementation of RQA-based textbooks. The design used is One Group Pretest-Posttest Design. This research was carried out in the chemistry department of Universitas Negeri Surabaya with the subjects of 25 undergraduate students. The results showed that: (1) Based on Bloom's taxonomy in Krathwohl's version, thinking ability obtain the percentage of undergraduate student achievement on each cognitive dimension include apply (C3) of 92.00, analyze (C4) of 68.00 , and create (C6) of 86.67; and (2) N-gain scores for each cognitive dimension of thinking ability obtained have medium and high criteria. Based on the results of the study, the RQA strategy can be used as an alternative to empower undergraduate students' thinking ability.
\end{abstract}

\section{Keywords— RQA strategy, empowering thinking skills}

\section{INTRODUCTION}

One of the ways to improve the quality of education in tertiary institutions is to utilize learning resources. The statement is in line with the opinion that one of the factors that cause the low quality of lectures, among others, is not yet optimally utilized learning resources [1]. This is further complicated by a condition where lecturers dominate lecture activities, which should be done by utilizing varied learning resources. Based on this, to obtain optimal learning results, undergraduate students are required not only to rely on what is happening in the classroom but must be able and willing to explore the variety of learning resources needed.

The Process and Learning Outcomes Assessment of Chemistry (PLOAC) course in the chemistry department is held for all chemistry education study program undergraduate students as prospective teachers, including in superior classes. The PLOAC course discusses the basic concepts of assessment, design, and application in chemical materials. The materials in the PLOAC course have theoretical characteristics or in the form of reading texts. Based on the characteristics of the material in the PLOAC course, the ability to read texts properly and in an organized manner is needed so that the terms and concepts contained in the material can be well understood and the quality of lectures can be improved. Excellent undergraduate students are expected to have the ability to communicate in English. Therefore, textbooks have been developed in the PLOAC courses in chemistry education courses in excellent classes in English. This is in line with the opinion of an expert that textbooks are teaching materials sourced from several kinds of literature that are relevant to basic competencies and subject matter and facilitate undergraduate students in the lecture process [2]. This statement is reinforced by the results of research that found that the activities in textbooks can help undergraduate students in building their own knowledge [3].

One of the constructivist learning strategies that can be used in accordance with facts related to the characteristics of the material in the PLOAC course and set forth in the Textbook is Reading, Questioning, and Answering (RQA) learning [4]. The RQA strategy begins with the reading stage where undergraduate students are given the task to read and understand the material reading, identify important ideas and find keywords so they are able to find essential concepts in the material, then at the questioning stage undergraduate students make a list of questions related to important concepts which is found when observing the material, and learning ends at the answering stage where undergraduate students predict the answers to the questions that have been made. Learning RQA is able to train undergraduate students to be serious in reading and understanding the contents of reading, helping undergraduate students in finding parts of substantial reading content so that when learning takes place undergraduate students already have concepts about the material they are learning [5]. The results of previous studies have found that textbooks that have been developed through R\&D in the Process and Learning Outcomes Assessment of Chemistry (PLOAC) course in chemistry majors at Surabaya State University, Indonesia have fulfilled valid criteria based on criteria for construct, content, language, and readability, and suitability with RQA learning, so that it is feasible to be implemented in lectures [6].

The learning process involves the maximum mental process of undergraduate students, not only requires undergraduate students to simply listen, take notes, but also 
requires undergraduate student activities in the process of thinking. However, in learning it must also be able to build a dialogical atmosphere and continuous question and answer process that is directed to improve and enhance students' thinking abilities, then the ability to think can help undergraduate students to gain knowledge that they construct themselves [7]. The Mastery of thinking ability is a fundamental process that enables undergraduate students to overcome various problems and is considered as the most important component of success in the 21 st century. Various educational research results have shown that thinking ability can motivate undergraduate students to think in various disciplines. Based on the description above, in this study, a measurement of undergraduate students' thinking ability was carried out by implementing an RQA-based textbook that researchers had developed previously and was feasible based on the validator's evaluation.

\section{METHODS}

The targets of this study were 25 undergraduate students of the chemical education program at the State University of Surabaya, Indonesia. The research instrument used the ability to think test in the form of multiple-choice with 7 items. The results of this study were analyzed by descriptive quantitative.

This research was pre-experimental design with One Group Pretest Posttest Design [8].

\begin{tabular}{lllll}
\hline \multicolumn{2}{c}{ Measurement } & & Treatment & \multicolumn{1}{c}{ Measurement } \\
\hline \multicolumn{2}{c}{$\mathbf{O}_{\mathbf{1}}$} & & & \multicolumn{1}{c}{$\mathbf{O}_{2}$} \\
\hline Notes: & $\mathrm{O}_{1}$ & $=$ & Pretest undergraduate student' thinking ability. \\
& $\mathrm{X}_{1}$ & $=$ & Treatment using textbook based on RQA \\
& $\mathrm{O}_{2}$ & $=$ & Posttest undergraduate student' thinking ability.
\end{tabular}

The research begins with a pretest about undergraduate students' thinking abilities, followed by the implementation of learning using RQA-based textbooks based on the learning syntax of Reading Questioning and Answering (RQA), namely: 1) undergraduate students are given the task of reading lecture material, 2) undergraduate students are asked to arrange questions. The questions compiled must represent the main idea of the reading content, and 3) undergraduate students are asked to answer questions that have been prepared in writing. Activities at the questioning and answering stage are to train undergraduate students' thinking skills by referring to the revised dimension of knowledge from Bloom's taxonomy [9] including remembering, understanding, applying, analyzing, evaluating and creating. The activity ended with a posttest to find out the thinking ability of undergraduate students.

The pretest-posttest score on the measurement of undergraduate students' thinking skills is converted to the total value and the percentage of achievement of each indicator is calculated. Undergraduate students are said to succeed in each indicator of the ability to think if they have a minimum percentage of achievement of $70 \%$. The Improving of thinking ability test results are calculated using gain scores. Descriptive analysis of N-gain using N-Gain criteria, namely: 1) "N-gain-high", if $<\mathrm{g}>>0.7$; 2) "N-gain-medium", if $0.3<<\mathrm{g}>\leq 0.7$; and 3) "N-gain-low", if $<\mathrm{g}>\leq 0.3$. [10].

\section{RESULTS AND DISCUSSIONS}

Thinking ability is the ability of undergraduate students to use concepts, principles, and theories into concrete situations in problem-solving shown by scores obtained by undergraduate students in thinking ability tests (pretest and posttest) for Authentic Assessment of Knowledge, Skills, and Attitude material in chemistry subject. The questions used in measuring thinking ability are questions that require undergraduate students to conduct thinking processes based on indicators of thinking ability.

There are seven items used to measure undergraduate students' thinking abilities. The relationship between the main concepts in the Authentic Assessment of Knowledge, Skills, and Attitude material in chemistry subject with indicators of thinking ability made, is presented in Table 1.

TABLE I. RELATIONSHIP BETWEEN THE MAIN CONCEPTS OF MATERIALS WITH INDICATORS OF THINKING ABILITY

\begin{tabular}{|c|c|c|}
\hline Main Concepts & Number & Indicators \\
\hline \multirow{7}{*}{$\begin{array}{l}\text { Knowledge assessment in } \\
\text { chemistry subject matter, } \\
\text { basic competencies, } \\
\text { lesson plan, syllabus, } \\
\text { written test, oral test, } \\
\text { assignment, true-false, } \\
\text { multiple choice, match } \\
\text { up, stuffing test, essay, } \\
\text { quizzes, task, objective } \\
\text { test, selection, } \\
\text { placement, diagnostic, } \\
\text { formative, summative, } \\
\text { writing rules, qualitative } \\
\text { analysis, skill } \\
\text { assessment, performance } \\
\text { assessment, project, } \\
\text { portfolio, product, } \\
\text { attitude assessment, self- } \\
\text { assessment. }\end{array}$} & 1. & $\begin{array}{l}\text { Identifying the assessment of } \\
\text { the knowledge, skills, attitudes } \\
\text { in the learning process in } \\
\text { chemistry subject matter. }\end{array}$ \\
\hline & 2. & $\begin{array}{l}\text { Analyzing the characteristics of } \\
\text { various knowledge assessment } \\
\text { techniques in chemistry subject } \\
\text { matter. }\end{array}$ \\
\hline & 3. & $\begin{array}{l}\text { Analyzing the characteristics of } \\
\text { various skill assessment } \\
\text { techniques in chemistry subject } \\
\text { matter. }\end{array}$ \\
\hline & 4. & Developing skills assessment. \\
\hline & 5. & $\begin{array}{l}\text { Analyzing the characteristics of } \\
\text { various attitude assessment } \\
\text { techniques in chemistry subject } \\
\text { matter. }\end{array}$ \\
\hline & 6. & Developing attitude assessment. \\
\hline & 7. & $\begin{array}{l}\text { Developing skill and attitude } \\
\text { assessment rubric in chemistry } \\
\text { subject matter. }\end{array}$ \\
\hline
\end{tabular}

Based on Table 1, indicators created to measure undergraduate students' thinking abilities include applying (C3), analyzing (C4), and creating (C6). Undergraduate student pretest and posttest results on Authentic Assessment of Knowledge, Skills, and Attitude material in chemistry subject are presented in Fig. 1 


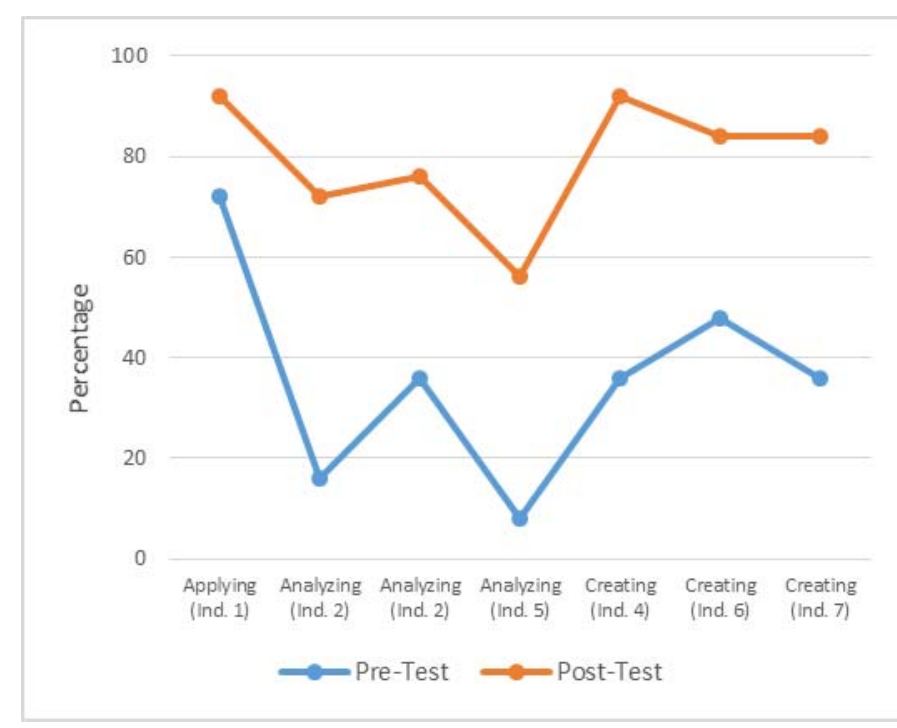

Fig. 1. Achievement of Thinking Abilities Indicators

Fig. 1 reveals a comparison of the percentage of achievement of each undergraduate student's thinking ability, including applying, analyzing, and creating. Each thinking ability changes from pretest to posttest in various ways. The facts show that the ability to think the analysis in indicator 5 has the lowest percentage of achievement.

The undergraduate students' thinking ability has been trained through the implementation of RQA-based textbooks. Undergraduate Students have been trained in the process of thinking to build an understanding of the contents of written readings and practice to develop thinking ability through the arrange of questions related to the concept of the material. This is consistent with the opinion that reading is a way to see and understand the contents of what is written and read is a thought process to build understanding, knowledge, and experience, and also interactive language communication between readers and writers through text [11].

In the ability to think of applying, undergraduate students' thinking ability is measured through indicators that are identifying the assessment of the knowledge, skills, attitudes in the learning process in chemistry subject matter. The success of undergraduate students in the apply indicator is shown by the percentage of achievement of $92 \%$. This means that undergraduate students have been able to apply various concepts related to the realm of knowledge, skills, and attitudes in the learning process in chemistry subject matter in real problems. Nevertheless, there are still some undergraduate students who are wrong in giving meaning to the behavior contained in the basic competencies in the curriculum, so undergraduate students have not been able to identify the assessment of the knowledge, skills, attitudes in the learning process in chemistry subject matter correctly.

For thinking skills analyzing the characteristics of various knowledge and skills assessment techniques in chemistry subject matter, undergraduate students have succeeded because they have an achievement percentage of $72.00 \%$ and $76.00 \%$. However, the ability to analyze the characteristics of various attitude assessment techniques in subject matter chemistry, undergraduate students only have a percentage of achievement of $56.00 \%$. This is due, some undergraduate students are less able to disclose information that has been obtained and decide on a form of knowledge structure through the breakdown of relevant knowledge. For example in chemical practicum activities, various attitude assessment techniques should be applied such as honesty, discipline, and cooperation, but students still have difficulty in determining the application of appropriate attitude assessment techniques.

The ability to think analyzing is the ability to divide and describe knowledge or problem into an important and unimportant part and look for the relationship of the components of knowledge [12]. Another opinion states that the ability to think to analyze break material into constituent parts and determine how parts relate to one another and to an overall structure or purpose. Analysis thinking ability consists of differentiating aspects, organizing aspects, and attributing aspects [9]. The aspect of sorting is the ability to sort or divide a part of knowledge between relevant or irrelevant parts as well as parts that are important or not important. Aspects of organizing are the ability to determine the elements in knowledge and know the role of each element in making a knowledge structure. Attributing aspect is the ability to express information that has been obtained in the form of conclusions to determine the perspective behind knowledge. The ability to analyze can develop problemsolving skills, analyze data, and use information wisely. The ability to think of analysis is a cognitive level higher than the ability to understand and apply because to have the ability to analyze someone must be able to understand the contents as well as the organizational structure.

In the ability to think to create, undergraduate students' thinking ability is measured through indicators namely developing skills assessment, developing attitude assessment, and developing skills and attitude assessment rubric in chemistry subject matter. The success of undergraduate students in indicators of creating, shown by the percentage of achievement of $92 \%, 84 \%$, and $84 \%$. This means that undergraduate students have been able to create is to put elements together to form a coherent or functional whole; reorganizing elements into a new pattern or structure; inventing a product [9]. This is in line with the opinion which states that one of the important thinking ability to be developed in the field of education is creative thinking ability $[13 ; 14]$. Creative thinking is cognitive activity in finding solutions to solve a problem [15]. Creative thinking is an original and reflective way of thinking and produces a complex product. Included in creative thinking is to synthesize ideas, generate new ideas, and determine the effectiveness of existing ideas.

The facts show that through the implementation of textbooks based on RQA, undergraduate students' creative thinking skills have been achieved. This is consistent with the opinion that creative thinking skills can be developed from several abilities such as the ability to solve problems, the ability to write and read various sources [16]. Reading activities carried out in a structured and organized manner can develop creative thinking skills [17]. Undergraduate students who easily understand a reading well can increase their creative thinking ability [18]. In the reading text, there are many main ideas for developing creative ideas [19].

Research finding states that reading activities have a positive relationship with creative thinking skills because 
reading activities require critical thinking skills, analytical, expressive abilities, and the process of discovery [16]. Undergraduate students who spend more time reading can improve their creative thinking skills, including the ability to develop ideas or ideas to solve problems.

To find out the improvement of undergraduate students thinking ability, N-Gain is used, as presented in Table II.

TABLE II. LASSIFICATION OF N-GAIN ABILITY THINKING UNDERGRADUATE STUDENTS

\begin{tabular}{|c|c|c|c|}
\hline Indicators & $\begin{array}{c}\text { \% Pretest } \\
\text { Achievement }\end{array}$ & $\begin{array}{c}\text { \% Posttest } \\
\text { Achievement }\end{array}$ & $\begin{array}{l}\text { N-Gain } \\
\text { (Criteria) }\end{array}$ \\
\hline $\begin{array}{l}\text { Identifying the } \\
\text { assessment of the } \\
\text { knowledge, skills, } \\
\text { attitudes in the } \\
\text { learning process in } \\
\text { chemistry subject } \\
\text { matter. }\end{array}$ & 72.00 & 92.00 & 0.71 (High) \\
\hline $\begin{array}{l}\text { Analyzing the } \\
\text { characteristics of } \\
\text { various knowledge } \\
\text { assessment techniques } \\
\text { in chemistry subject } \\
\text { matter. }\end{array}$ & 16.00 & 72.00 & $\begin{array}{c}0.67 \\
\text { (Medium) }\end{array}$ \\
\hline $\begin{array}{l}\text { Analyzing the } \\
\text { characteristics of } \\
\text { various skill } \\
\text { assessment techniques } \\
\text { in chemistry subject } \\
\text { matter. }\end{array}$ & 36.00 & 76.00 & $\begin{array}{c}0.63 \\
\text { (Medium) }\end{array}$ \\
\hline $\begin{array}{l}\text { Developing skills } \\
\text { assessment. }\end{array}$ & 36.00 & 92.00 & 0.88 (High) \\
\hline $\begin{array}{l}\text { Analyzing the } \\
\text { characteristics of } \\
\text { various attitude } \\
\text { assessment techniques } \\
\text { in chemistry subject } \\
\text { matter. }\end{array}$ & 8.00 & 56.00 & $\begin{array}{c}0.52 \\
\text { (Medium) }\end{array}$ \\
\hline $\begin{array}{l}\text { Developing attitude } \\
\text { assessment. }\end{array}$ & 48.00 & 84.00 & $\begin{array}{c}0.69 \\
\text { (Medium) }\end{array}$ \\
\hline $\begin{array}{l}\text { Developing skill and } \\
\text { attitude assessment } \\
\text { rubric in chemistry } \\
\text { subject matter. }\end{array}$ & 36.00 & 84.00 & $\begin{array}{c}0.75 \\
\text { (High) }\end{array}$ \\
\hline
\end{tabular}

From Table II, it is known that the value of N-Gain in undergraduate students' thinking ability is mostly in the moderate classification, namely at intervals of $0.30 \geqslant \mathrm{~N}$ Gain $\leqslant 0.70$. Undergraduate students are said to succeed in each indicator of thinking ability if they have a minimum percentage of achievement of $70 \%$. Based on Table II, undergraduate students still have not succeeded in completing one indicator namely Analyzing the characteristics of various attitude assessment techniques in chemistry subject matter.

The ability to think is a way for someone to improve the quality of the results of thinking using systematic techniques of thinking and producing intellectual power [20]. Criteria in the process of thinking ability are clarity, level of accuracy, the level of precision, relevance, logic of thinking used, breadth of perspective, depth of thought, honesty, completeness of information and how the implications of the proposed solution, it is necessary to teach a course so that can an increase in undergraduate students' thinking abilities.
This study revealed that the steps of RQA learning proved effective in improving undergraduate students' thinking ability. One of the learning steps in RQA is reading. Reading habits will prepare a person to be a productive human being and the ability to read and learn new things can keep the brain healthy [21].

Further explained that the ability to read can bring up the ability to understand and comprehend the new subject matter. In addition through reading habits, a person can be trained to sort out authentic information, practice thinking ability, and develop skills specifically analytical skills. Adequate reading comprehension will make it easier for undergraduate students to get information from various written sources because most of the knowledge learned is in written material. Some educational studies reveal a close relationship between reading habits and academic success [22].

\section{CONCLUSION}

Based on the description of the research results above, the conclusions that can be drawn are: (1) Based on Bloom's taxonomy in Krathwohl's version, thinking ability obtain the percentage of undergraduate student achievement on each cognitive dimension include applying (C3) of 92.00, analyzing (C4) of 68.00 , and creating (C6) of 86.67; and (2) $\mathrm{N}$-gain scores for each cognitive dimension of thinking ability obtained have medium and high criteria. Based on the results of the study, the RQA strategy can be used as an alternative to empower undergraduate students' thinking ability.

\section{ACKNOWLEDGMENT}

The author thanks first-year undergraduate students of the Chemistry Education program as users who are directly involved in implementing an RQA-based textbook.

\section{REFERENCES}

[1] E. Mulyasa. Menjadi Guru Profesional menciptakan Pembelajaran Kreatif dan Menyenangkan. Bandung: Rosdakarya. 2007.

[2] A. Prastowo. Paduan Keratif Membuat Bahan Ajar Inovatif, Jogyakarta: Diva Press, 2011.

[3] U. Azizah dan H. Nasrudin.. Pemberdayaan Kecakapan Berpikir Siswa SMA Bertaraf Internasional Melalui Pengembangan Perangkat Pembelajaran Materi Redox Reaction Berorientasi "Group Investigation Cooperative."Jurnal Pendidikan dan Pembelajaran (JPP), 2013, Terakreditasi ISSN 2302-996X. Vol 20, no 2, pp. 141151

[4] A.D. Corebima, A. D. Pengalaman Berupaya Menjadi Guru Profesional. Pidato Pengukuhan Guru Besar pada FMIPA UM. Disampaikan pada Sidang Terbuka Senat UM, Malang, 30 Juli. 2009.

[5] Sumampouw, Herry. 2012. Strategi RQA dalam Perkuliahan Genetika Berbasis Metakognitif dan Retensi. Makalah yang Disampaikan Pada Seminar Nasional MIPA dan Pembelajarannya FMIPA Universitas Negeri Malang. 15 Oktober 2012.

[6] H. Nasrudin, U. Azizah, and Muchlis. The Validity Of Textbook Based on Reading, Questioning and Answering (RQA) For Leading Students In Assessment Course at Chemistry Department UNESA. Journal of Chemistry Education Research, 2018, vol 2, no 2, pp. 45 48 . 
[7] S. Sagala. Konsep dan Makna Pembelajaran. Bandung: Alfabeta. 2007

[8] J.R. Fraenkel and N. E. Wallen. How to Design and Evaluate Research In Education. Fifth Edition. Boston: Mc Graw Hill. 2003.

[9] L. W. Anderson and D. R. Krathwohl. (eds). A taxonomy for learning teaching and Assessing. A Revision of Bloom's Taxonomy of education Objectives. New York: Addisin Wesley. 2001.

[10] R. Hake 2002. Relationship of individual student normalized learning gains in mechanics with gender, high school physics, and pretest scores on mathematics and spatial visualization. Tersedia pada: http://www.physics.indiana.edu/. Diakses pada tanggal 10 Juli 2012.

[11] Yu Hui, L., Li Rong, Z., \& Yue, N.(2010). Application of Schema Theory in Teaching College English Reading. Canadian Social Science,6(1): 59-65.

[12] M. Yaumi. Prinsip-Prinsip Desain Pembelajaran. Jakarta: Kencana. 2013.

[13] D. W. Chan. 2007. Creative Teaching in Hong Kong Schools: Constraints and Challenges. Hong Kong Educational Research Journal, 22(1): 1-11

[14] H. Turkmen. 2015. Creative Thinking Skills Analyzes Of Vocational High School Students Journal Of Educational And Instructional Studes In The World, 5(1): 74-84.

[15] K. Adams. The Sources Of Innovation On Creativity . A Paper Commsioned by The National Center On Education And The Economy For New Commision on the Skills Of The American Workforce. National Center On Education and The Economy. 2005.

[16] A. Wang. 2011. Context of Creative Thinking: A Comparison on Creative Performance of Student Teachers in Taiwan and the United States. Journal of International and CrossCurtural Studies. 2, (1), 114.
[17] I. M. E. Acosta and M. M. Ferri. .(2010) Reading Strategies To Develop Higher Thinking Skills For Reading Comprehension. Estrategias De Lectura Para El Desarrollo De Habilidades De Pensamiento Para La Comprensión De Lectura. 2010. Vol 12, no. 1. $107-123$

[18] F. King. Special Education in Irish Classrooms: A Practical Guide, Dublin; Primary ABC. 2006.

[19] I. Sturgell. (2008) . Touchstone Texts: Fertile. Ground F or C reativity Reading Teacher. 2008. Vol 61, no 5, pp, 411-414.

[20] R. Paul and E. Linda. 2005. The Miniature Guide to Critical Thinking "CONCEPTS \& TOOLS". The Foundation of Critical Thinking. California.

[21] J. Minar. 2010. Reading Books is Important to Development, (Online), (http://www.articleclick.com/Article/ReadingBooks-IsImportant-To-Development/3238, diakses 26 Juni 2018)

[22] P. Shoebottom. 2007. The Importance of Reading. (http://www.familyresource.com/parenting/childdevelopment/whyreading-is-so-important-forchildren, diakses 19 Juli 2018). 